\title{
Evaluation of Postoperative Complications after Laparoscopic Sleeve Gastrectomy with Omentopexy versus Conventional Laparoscopic Sleeve Gastrectomy
}

\author{
MOHAMED H. ZAID, M.D.; KARIM FAHMY, M.D.; AHMED G. OSMAN, M.D. and AHMED KHALIL, M.D. \\ The Department of General Surgery and Medical Oncology, Faculty of Medicine, Ain Shams University, Cairo, Egypt
}

\begin{abstract}
Background: Laparoscopic sleeve gastrecomy is the most popular bariatric procedure with good outcome and acceptable complications (bleeding, leakage, stenosis or twist).

Aim of Study: To evaluate the role of omentopexy reinforcement of staple line in reducing postoperative leakage, bleeding and gastric twist.

Patients and Methods: This is a prospective cohort study conducted at Ain-Shams University Hospitals, in the period From May 2017 to November 2020. Four hundred morbid obese patients were recruited for this study. Ethical approval was obtained from the Ethical Committee of Ain Shams University Hospitals, and informed written consents were obtained from all patients.
\end{abstract}

Results: Our study included 200 patients who underwent Laparoscopic sleeve gastrectomy, one hundred patients underwent LSG without omentopexty (group A) and the other one hundred patients underwent LSG with omentopexy (group B). As regards the age, group A (control group) mean age of $35.74 \pm 7.88$ while group B (omentopexy group) mean age of $35.6 \pm 7.85$. The mean BMI $40.95 \pm 5.25$ in group A while $40.94 \pm 5.02$ in group B. Three cases of group A $(1.5 \%)$ while group B had no cases of postoperative leakage with $p$-value is 0.24 . Two cases of group A had postoperative bleeding (1\%) while it did not happen in group B with $\mathrm{P}$ value is 0.499 . Gastric twist had happened in only 1 case of group A $(0.5 \%)$ while did not happen in any cases of group B, P value is 1 . The mean operative time in group A $46.08 \pm 10.95$ minutes, while $67.49 \pm 9.19$ minutes in group B with $p$-value 0.00 .

Conclusion: LSG with omentopexy reduce rate of postoperative complications (bleeding, leakage and gastric twist) but need longer time than conventional LSG.

Key Words: Laparoscopic sleeve gastrectomy-Omentopexy.

\section{Introduction}

OBESITY considered one of the major health problems, over than 650 million adults suffering from morbid obesity [1].

Correspondence to: Dr. Mohamed H. Zaid, E-Mail: hamdymhz@gmail.com
Obesity is considered a risk factor for developing metabolic syndrome that includes insulin resistance diabetes mellitus, hypertension and dyslipidaemia [2,3]

Nowadays laparoscopic sleeve gastrecomy and laparoscopic gastric bypass are surgical methods for management of morbid obesity if failed conservative management of obesity [4] .

Laparoscopic sleeve gastrecomy is the most popular bariatric procedure with good outcome and acceptable complications [5].

Bleeding and leakage are the major early postoperative complication with low incidence but affect patient recovery and prolong hospital stay $[6,7]$.

Leakage mainly occur at gastro-esophageal junction (90\% of patients), staple line is the common site of bleeding while stenosis mainly near incisura angularis [8-11].

Staple line reinforcement used to reduce postoperative complications (bleeding, leakage and gastric twist) [11]

Multiple methods used for staple line reinforcement (SLR) either oversewing, inverting suture line or omentopexy to staple line [11].

Aim of the work:

To evaluate the role of omentopexy reinforcement of staple line in reducing postoperative leakage, bleeding and gastric twist.

\section{Patients and Methods}

\section{Patients:}

This is a prospective cohort study conducted at Ain-Shams University Hospitals, in the period 
From May 2017 to November 2020. Four hundred morbid obese patients were recruited for this study. Ethical approval was obtained from the Ethical Committee of Ain Shams University Hospitals, and informed written consents were obtained from all patients.

\section{Inclusion criteria:}

- Obese patients with BMI more than 35 or obese patients with BMI more than 30 with comorbidities.

- Age from 18 to 55 years.

- Cooperative and psychologically stable patients.

Exclusion criteria:

- Patients with cirrhotic liver.

- Patients with bleeding disorder.

\section{Preoperative assesment:}

All patients were subjected to clinical assessment including history (past medical, surgical, family history and history of hormone replacement or oral contraceptive pills intake) taking and clinical abdominal examination as well as the following investigations:

- Laboratory investigations: CBC, INR, urea and creatinine, liver enzymes, lipid profile, glycated hemoglobin, viral markers and TSH.

- Imaging: Pelvi-abdominal US, ECG, pulmonary function test, chest X-ray and Echocardiography.

\section{Operative details:}

All operations were performed laparoscopically. We used five port technique. After ports insertion we started to mobilize greater omentum from the stomach using legasure then we insert 36 Fr. Bougie then stomach transected using covadien stapler 4 $\mathrm{cm}$ from the pylorus to angle of his (the green reload $4.8 \mathrm{~mm}$ was used in the first fire then the blue reload $3.5 \mathrm{~mm}$ till complete stomach transaction) followed by mythelene blue test to assess leakage. In group B (omentopexy group) we underwent omentopexy to staple line using prolene 2/0 or PDS $2 / 0$ (Figs. 1,2,3).

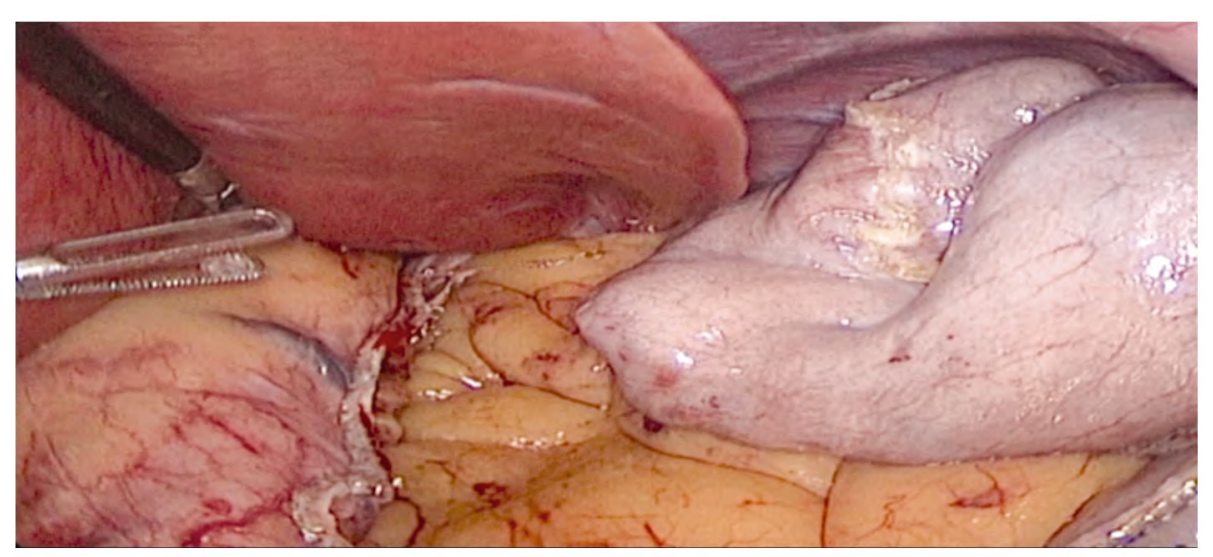

Fig. (1): Staple line after resection.

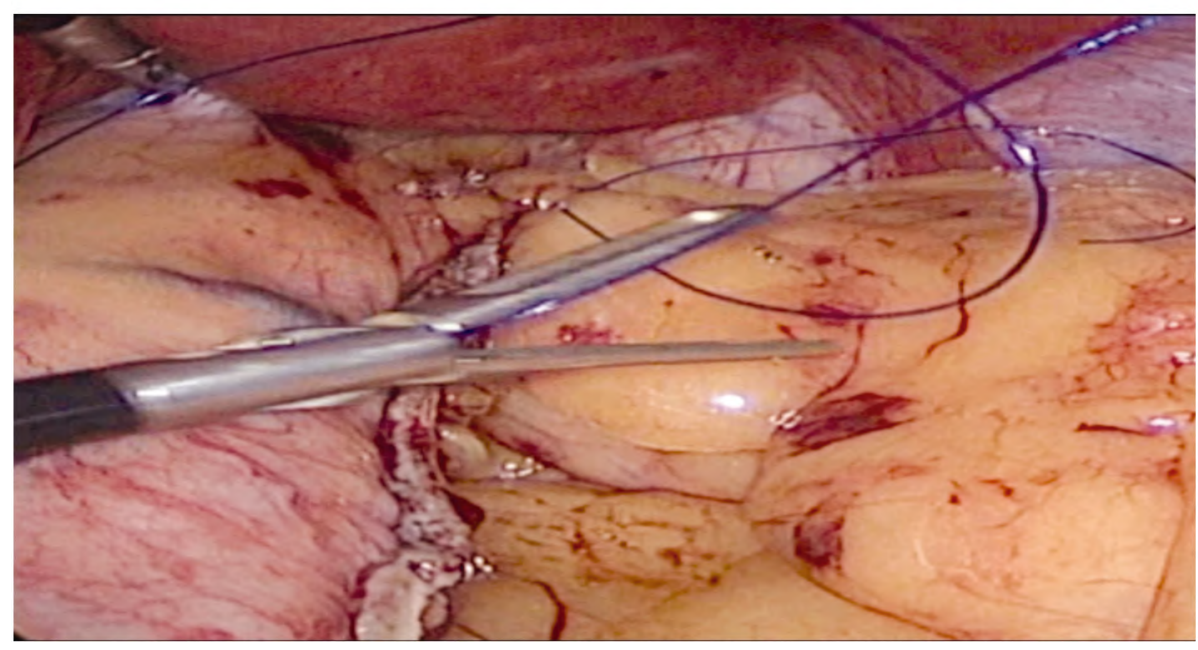

Fig. (2): Omentopexy of staple line. 

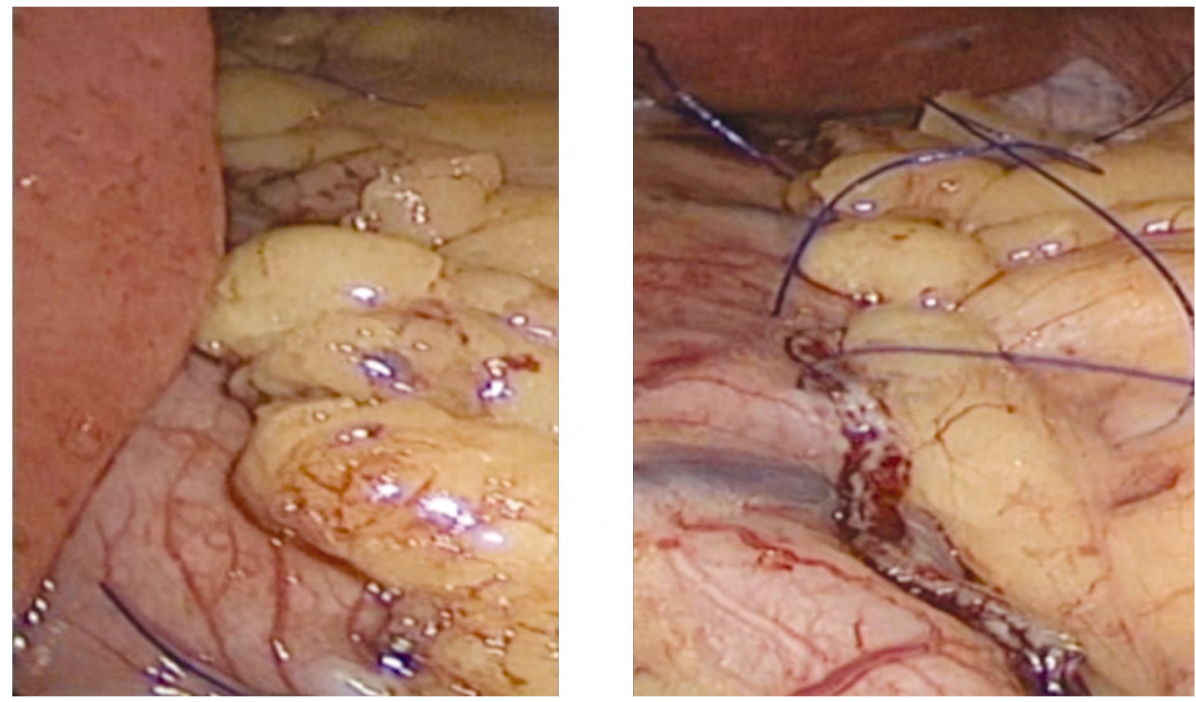

Fig. (3): After omentopexy.

\section{Results}

\section{Demographics:}

As regards the age, group A (control group) age range was between 18 and 55 with mean age of 35.74 and SD of 7 while group B (omentopexy group) had age ranging between 19 and 57 and mean age of 35.6 and SD of 7.8. For the sex, group A had 132 female patients (66\%) and 68 males (34\%) while group B (the omentopexy group) had 112 female patients (56\%) and 88 males (44\%). There was no statistically significant difference between the 2 groups as regards age; $p$-values were 0.85 and there was statistically significant difference between the 2 groups as regards sex; $p$-values 0.04 respectively. (Table 1 ).

For group A, BMI was ranging between 32 and 52.1 with mean BMI was 40.95 and SD of 5.25 while group B the BMI was ranging between 32 to 55.5 and mean of 40.94 and SD of 5. There is not statistically significant difference between the 2 groups as regards the BMI, $p$-value is 0.972 (Table 1).

Table (1): Patients Demographics and BMI.

\begin{tabular}{|c|c|c|c|c|c|}
\hline & $\begin{array}{l}\text { Control } \\
\text { group } \\
\text { No.=200 }\end{array}$ & $\begin{array}{l}\text { Omentopexy } \\
\text { group } \\
\text { No.=200 }\end{array}$ & $\begin{array}{c}\text { Test } \\
\text { value }\end{array}$ & $\begin{array}{c}p- \\
\text { value }\end{array}$ & Sig. \\
\hline $\begin{array}{l}\text { Age: } \\
\quad \text { Mean } \pm \text { SD } \\
\text { Range }\end{array}$ & $\begin{array}{l}35.74 \pm 7.88 \\
18-55\end{array}$ & $\begin{array}{l}35.60 \pm 7.85 \\
19-57\end{array}$ & $0.178 \bullet$ & 0.859 & NS \\
\hline $\begin{array}{l}\text { Sex: } \\
\text { Female } \\
\text { Male }\end{array}$ & $\begin{array}{l}132(66.0 \%) \\
68(34.0 \%)\end{array}$ & $\begin{array}{l}112(56.0 \%) \\
88(44.0 \%)\end{array}$ & $4.203 *$ & 0.040 & $\mathrm{~S}$ \\
\hline $\begin{array}{l}\text { BMI: } \\
\quad \text { Mean } \pm \text { SD } \\
\quad \text { Range }\end{array}$ & $\begin{array}{l}40.95 \pm 5.25 \\
32-52.1\end{array}$ & $\begin{array}{l}40.94 \pm 5.02 \\
32-55.5\end{array}$ & $0.035^{\bullet}$ & 0.972 & NS \\
\hline
\end{tabular}

$p$-value $>0.05$ : Non significant (NS). $p$-value $<0.05$ : Significant (S). $p$-value <0.01: Highly significant (HS).

*: Chi-square test. $\quad \bullet$ : Independent $t$-test.
Comorbidities and complications (Table 2 and Fig. 4):

Thirty two patients of group A had diabetes $(16 \%)$ while twenty eight patients of group B had diabetes (14\%) with no statistically significant difference between the two groups, $p$-value is 0.575 (Table 2).

$14 \%$ of group A patients had hypertension (28 patients) while group B the omentopey group $12 \%$ had hypertension (24 patients). No statistically significant difference between the 2 groups as regards hypertension, $p$-value is 0.55 (Table 2).

Hyperlipidemia was associated with obesity in 16 patients (8\%) of group A while in group B 12 patients $(6 \%)$ had hyperlipidemia, with no statistically significant difference between the 2 groups, $p$-value is 0.433 (Table 2).

Ischemic heart disease was associated with 4 patients only of group A ( $2 \%$ only) while for group B 4 patients also had ISHD ( $2 \%$ also) with no statistically significant difference between the 2 groups, $p$-value is 0.55 (Table 2).

Postoperative leakage happened only in 3 cases of group A (1.5\%) while group B had no cases of postoperative leakage, although the difference, it was not statistically significant with $p$-value is 0.24 (Table 2).

Post operative bleeding had occurred in 2 cases of group A $(1 \%)$ while it did not happen in group $B$ with no statistically significant difference, $p$ value is 0.499 (Table 2).

As regards postoperative perigastric collection, it occurred only is 2 cases of group A (1\%) while 
it did not occur in any cases of group B. Still not statistically significant difference with $p$-value was 0.499 (Table 2).

Gastric twist had happened in only 1 case of group A $(0.5 \%)$ while did not happen in any cases of group $\mathrm{B}, p$-value is 1 , not statistically significant (Table 2).

No mortality detected in both groups.

Table (2): Comorbidities and complications.

\begin{tabular}{|c|c|c|c|c|c|c|c|}
\hline & \multicolumn{2}{|c|}{$\begin{array}{l}\text { Control } \\
\text { group }\end{array}$} & \multicolumn{2}{|c|}{$\begin{array}{l}\text { Omentopexy } \\
\text { group }\end{array}$} & \multirow{2}{*}{$\begin{array}{c}\text { Test } \\
\text { value }\end{array}$} & \multirow[t]{2}{*}{$\begin{array}{c}p- \\
\text { value }\end{array}$} & \multirow[t]{2}{*}{ Sig } \\
\hline & No. & $\%$ & No. & $\%$ & & & \\
\hline $\begin{array}{c}\text { Diabetes: } \\
\text { No } \\
\text { Yes }\end{array}$ & $\begin{array}{l}168 \\
32\end{array}$ & $\begin{array}{l}84.0 \\
16.0\end{array}$ & $\begin{array}{l}172 \\
28\end{array}$ & $\begin{array}{l}86.0 \\
14.0\end{array}$ & $0.314^{*}$ & 0.575 & \\
\hline $\begin{array}{l}H T N: \\
\text { No } \\
\text { Yes }\end{array}$ & $\begin{array}{l}172 \\
28\end{array}$ & $\begin{array}{l}86.0 \\
14.0\end{array}$ & $\begin{array}{l}176 \\
24\end{array}$ & $\begin{array}{l}88.0 \\
12.0\end{array}$ & $0.354^{*}$ & 0.552 & \\
\hline $\begin{array}{l}\text { ISHD: } \\
\text { No } \\
\text { Yes }\end{array}$ & $\begin{array}{l}196 \\
4\end{array}$ & $\begin{array}{l}98.0 \\
2.0\end{array}$ & $\begin{array}{l}196 \\
4\end{array}$ & $\begin{array}{l}98.0 \\
2.0\end{array}$ & $\mathrm{~F}^{* *}$ & 1.000 & \\
\hline $\begin{array}{l}\text { Hyperlipidemia: } \\
\text { No } \\
\text { Yes }\end{array}$ & $\begin{array}{l}184 \\
16\end{array}$ & $\begin{array}{l}92.0 \\
8.0\end{array}$ & $\begin{array}{l}188 \\
12\end{array}$ & $\begin{array}{l}94.0 \\
6.0\end{array}$ & $0.614 *$ & 0.433 & \\
\hline $\begin{array}{c}\text { Leakage: } \\
\text { No } \\
\text { Yes }\end{array}$ & $3^{197}$ & $\begin{array}{l}98.5 \\
1.5\end{array}$ & $\begin{array}{l}200 \\
0\end{array}$ & $\begin{array}{l}100.0 \\
0.0\end{array}$ & $\mathrm{~F}^{* *}$ & 0.248 & \\
\hline $\begin{array}{l}\text { Perigatric } \\
\text { collection: } \\
\text { No } \\
\text { Yes }\end{array}$ & ${ }_{2}^{198}$ & $\begin{array}{l}99.0 \\
1.0\end{array}$ & $\begin{array}{l}200 \\
0\end{array}$ & $\begin{array}{l}100.0 \\
0.0\end{array}$ & $\mathrm{~F}^{* *}$ & 0.499 & $\mathrm{~N}$ \\
\hline $\begin{array}{l}\text { Gastric twist: } \\
\text { No } \\
\text { Yes }\end{array}$ & $\begin{array}{l}199 \\
1\end{array}$ & $\begin{array}{l}99.5 \\
0.5\end{array}$ & $\begin{array}{l}200 \\
0\end{array}$ & $\begin{array}{l}100 \\
0.0\end{array}$ & $\mathrm{~F}^{* *}$ & 1.000 & NS \\
\hline $\begin{array}{c}\text { Bleeding: } \\
\text { No } \\
\text { Yes }\end{array}$ & $2^{198}$ & $\begin{array}{l}99.0 \\
1.0\end{array}$ & $\begin{array}{l}200 \\
0\end{array}$ & $\begin{array}{l}100.0 \\
0.0\end{array}$ & $\mathrm{~F}^{* *}$ & 0.499 & NS \\
\hline
\end{tabular}

$p$-value $>0.05$ : Non significant (NS). $p$-value $<0.05$ : Significant (S). $p$-value <0.01: Highly significant (HS).

*: Chi-square test. $\quad * *$ : Fisher's exact test. $\quad \bullet$ Independent $t$-test.

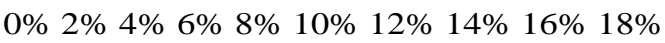

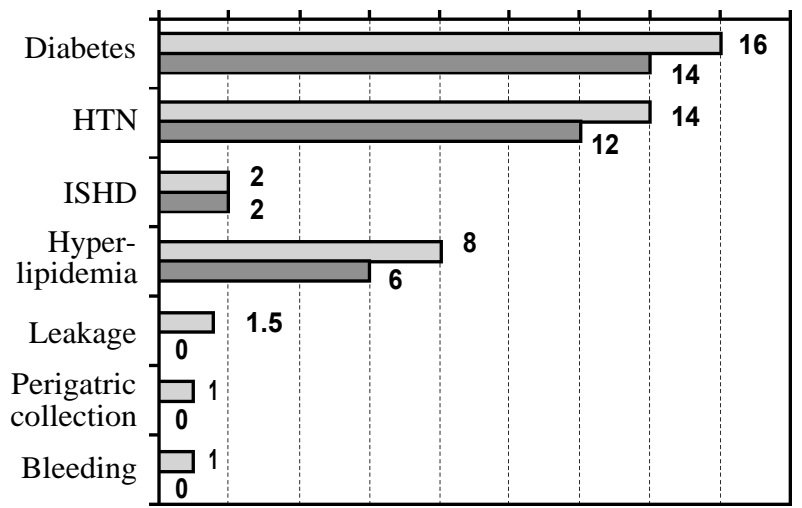

Control group $\square$ Omentopexy group

Fig. (4): Comorbidities and Complications.
As regards the operative time, group A operative time was ranging between 40 to 84 minutes with mean time 46.08 minutes and SD 10.95, while for group B the time range was between 50 to 100 minutes with mean time was 67.49 minutes and SD 9.19 minutes. This showed high statistically significant difference between the 2 groups with $p$-value 0.00 (Table 3 and Fig. 5).

As regards the hospital stay, Group A hospital stay was ranging between 1-4 days with mean stay 1.04 days and SD 0.27 days, while group B hospital stay was ranging between 1-1.5 days with mean hospital sat of 1.03 and SD 0.1. There is no statistically significant difference between the 2 groups as regards the hospital stay with $p$-value 0.432 (Table 3).

Table (3): Operative time and hospital stay.

\begin{tabular}{|c|c|c|c|c|c|}
\hline & $\begin{array}{l}\text { Control } \\
\text { group } \\
\text { No.=200 }\end{array}$ & $\begin{array}{c}\text { Omentopexy } \\
\text { group } \\
\text { No.=200 }\end{array}$ & $\begin{array}{c}\text { Test } \\
\text { value }\end{array}$ & $\begin{array}{c}p- \\
\text { value }\end{array}$ & Sig. \\
\hline \multicolumn{6}{|l|}{$\begin{array}{l}\text { Operative time } \\
\text { (min). }\end{array}$} \\
\hline $\begin{array}{l}\text { Mean } \pm \text { SD } \\
\text { Range }\end{array}$ & $\begin{array}{l}46.08 \pm 10.59 \\
4-84\end{array}$ & $\begin{array}{l}67.49 \pm 9.19 \\
50-100\end{array}$ & $-21.602 \bullet$ & 0.000 & HS \\
\hline \multicolumn{6}{|l|}{ Hospital stay } \\
\hline $\begin{array}{l}\text { (day): } \\
\text { Mean } \pm \text { SD } \\
\text { Range }\end{array}$ & $\begin{array}{l}1.04 \pm 0.27 \\
1-4\end{array}$ & $\begin{array}{l}1.03 \pm 0.10 \\
1-1.5\end{array}$ & $0.787 \bullet$ & 0.432 & NS \\
\hline
\end{tabular}

$p$-value $>0.05$ : Non significant (NS). $p$-value $<0.05$ : Significant $(\mathrm{S})$. $p$-value <0.01: Highly significant (HS).

$*$ : Chi-square test. $\quad \cdot$ : Independent $t$-test.

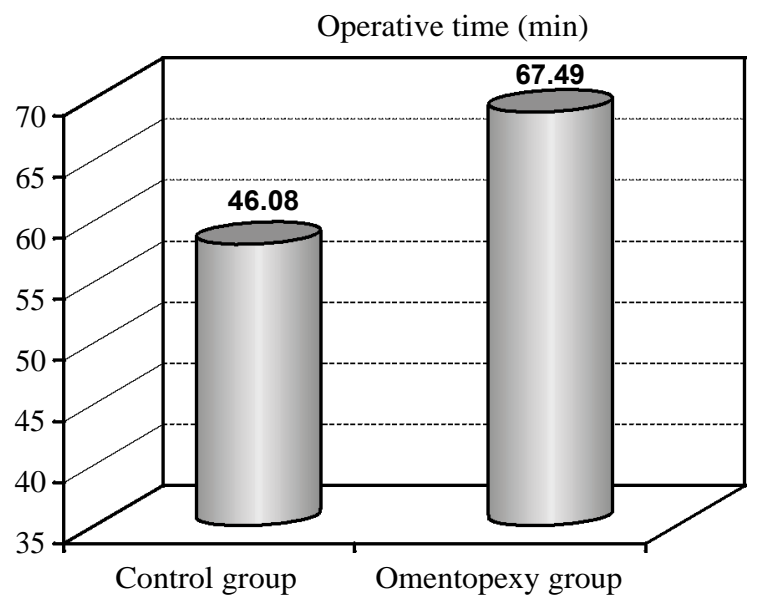

Fig. (5): Operative time

\section{Discussion}

Nowadays laparoscopic sleeve gastrecomy and laparoscopic gastric bypass are surgical methods for management of morbid obesity if failed conservative management of obesity [4]. 
Laparoscopic sleeve gastrecomy is the most popular bariatric procedure with good outcome and acceptable complications [5].

Bleeding and leakage are the major early postoperative complication with low incidence but affect patient recovery and prolong hospital stay $[6,7]$.

Multiple methods used for staple line reinforcement (SLR) either oversewing, inverting suture line or omentopexy to staple line to reduce postoperative complications (bleeding, leakage and gastric twist) [11]

LSG complications usually associated with increase hospital stay and risk of mortality [14]

In our study we evaluate role of omentopexy reinforcement of staple line in reducing postoperative leakage, bleeding and gastric twist in comparison with control group with no omentopexy.

In our study the operative time, group A operative time was ranging between 40 to 84 minutes with mean time 46.08 minutes, while for group B the time range was between 50 to 100 minutes with mean time was 67.49 minutes. This showed high statistically significant difference between the 2 groups with $p$-value 0.00 . There is extra time in omentopexy group that will be decreased by time with increase in learning curve.

Other studies reported that Bleeding from staple line after LSG ranges from 0 to $4.4 \%$ [9,12,13], while in our study Post operative bleeding had occurred in 2 cases of group A (1\%) while it did not happen in group B so LSG with staple line reinforcement with omentum reduce rate of bleeding but statistically no statistically significant difference.

The rate of leak in literature $1 \%$ up to $3 \%$ with 9\% mortality related to leak [15-17].

In our study Postoperative leakage happened only in 3 cases of group A (1.5\%) while group B had no cases of postoperative leakage, reinforcement of staple line with omentopexy redicing leakage than conventional LSG but not statistically significant.

Himpens J et al., and Musella $\mathrm{M}$ et al., reported that SLR (staple line reinforcement) is reducing rate of post operative complications (leakage and bleeding) $[15,18]$.

D'Ugo $S$ et al., and Carandina $S$ et al., reported in their meta-analysis that there was no significant difference between SLR and simple LSG as regard postoperative leakage [11,19].

Chang et al., [20] reported that omentopexy prevent gastric twist that lead to stenosis and increase risk of gastric leak, in our study Gastric twist had happened in only 1 case of group A $(0.5 \%)$ while did not happen in any cases of group B.

There are multiple reinforcement techniques used such as oversewing, biological Sealants, inverting suture line or omentopexy to staple line to reduce rate of postoperative complications.

As regard postoperative leakage in three cases in group A are managed conservatively with stent and two cases need pigtail insertion in perigastric collection.

Two patients in group A developed postoperative bleeding that managed conservatively with resuscitation and blood transfusion but one of them needs laparoscopic exploration after bleeding and evacuation of intra-abdominal hematoma.

Patient who developed gastric twist in group A presented with recurrent vomiting with no ability for oral uptake that managed by laparoscopic untwist with fixation of stomach by suture in peripancreatic fascia.

\section{Conclusion:}

LSG with omentopexy reduce rate of postoperative complications (bleeding, leakage and gastric twist) but need longer time than conventional LSG. More studies are needed to confirm results.

Acknowledgement: The authors declare that they have no conflict of interest.

\section{References}

1- Online source: https://www.who.int/en/news room/ factsheets/detail/obesity-and-overweight Access: 15.03.2020.

2- HAN T.S. and LEAN M.E.: A clinical perspective of obesity, metabolic syndrome and cardiovascular disease. JRSM Cardiovasc. Dis., 5: 2048004016633371, 2016.

3- WOJCIAK P., PAWLUSZEWICZ P., DIEMIESZCZYK I., et al.: Laparoscopic sleeve gastrectomy: A study of efficiency in treatment of metabolic syndrome components, comorbidities and influence on certain biochemical markers. Videosurgery Miniinv, 15: 136-47, 2020.

4- WELBOURN R., HOLLYMAN M., KINSMAN R., et al.: Bariatric surgery worldwide: Baseline demographic description and one-year outcomes from the Fourth IFSO Global Registry Report 2018. Obes. Surg., 29: 782-95, 2019. 
5- ANGRISANI L., SANTONICOLA A., IOVINO P., et al.: IFSO worldwide survey 2016: Primary, endoluminal, and revisional procedures. Obes Surg., 28: 3783e3794, 2018.

6- GAGNER M., DEITEL M., ERICKSON A.L. and CROSBY R.D.: Survey on laparoscopic sleeve gastrectomy (LSG) at the fourth international consensus summit on sleeve gastrectomy. Obes. Surg., 23: 2013e2017, 2013.

7- ABDALLAH E., EMILE S.H. and ELFEKI H.: Laparoscopic sleeve gastrectomy with or without staple line inversion and distal fixation to the transverse mesocolon: Impact on early postoperative outcomes. Obes. Surg., 27 323e329, 2017.

8- MANOS T., NEDELCU M., COTIRLET A., EDDBALI I., GAGNER M. and NOEL P.: How to treat stenosis after sleeve gastrectomy? Surgery for obesity and related diseases. Off J. Am. Soc. Bariatric Surg., 13: 150e154, 2017.

9- SAKRAN N., GOITEIN D., RAZIEL A., et al.: Gastric leaks after sleeve gastrectomy: A multicenter experience with 2,834 patients. Surg. Endosc., 27: 240e245, 2013.

10- AURORA A.R., KHAITAN L. and SABER A.A.: Sleeve gastrectomy and the risk of leak: A systematic analysis of 4,888 patients. Surg. Endosc., 26: 1509e1515, 2012.

11- D'UGO S., GENTILESCHI P., BENAVOLI D., et al.: Comparative use of different techniques for leak and bleeding prevention during laparoscopic sleeve gastrectomy: A multicenter study. Surg. Obes. Relat. Dis. Off J. Am. Soc. Bariatric Surg., 10: 450e454, 2014.

12- BURGOS A.M., BRAGHETTO I., CSENDES A., MALUENDA F., KORN O., YARMUCH J. and GUTIERREZ L.: Gastric leak after laparoscopic-sleeve gastrectomy forobesity. Obes. Surg., 19: 1672-1677, 2009.

13- MARQUEZ M.F., AYZA M.F., LOZANO R.B., del MAR RICO MORALES M, GARCíA DíEZ J.M. and POUJOULET R.B.: Gastric leak after laparoscopic sleeve gastrectomy. Obes. Surg., 20: 1306-1311, 2010.
14- VAN RUTTE P.W., SMULDERS J.F., de ZOETE J.P. and NIENHUIJS S.W.: Outcome of sleeve gastrectomy as a primary bariatric procedure. Br. J. Surg. May, 101 (6): 661-8 PMID: 2472301, 2014.

15- HIMPENS J., DOBBELEIR J., PEETERS G.: Long-term results of laparoscopic sleeve gastrectomy for obesity. Ann. Surg., 252 (2): 319-24 PMID: 20622654, 2010.

16- OSLAND E., YUNUS R.M., KHAN S., ALODAT T. MEMON B. and MEMON M.A.: Postoperative Early Major and Minor Complications in Laparoscopic Vertical Sleeve Gastrectomy (LVSG) Versus Laparoscopic Rouxen-Y Gastric Bypass (LRYGB) Procedures: A MetaAnalysis and Systematic Review. Obes. Surg., 26 (10): 2273-84 PMID: 26894908, 2016.

17- GAGNER M., HUTCHINSON C. and ROSENTHAL R.: Fifth International Consensus Conference: Current status of sleeve gastrectomy. Surg. Obes. Relat. Dis., 12(4):7506 Epub2016 Jan 25. PMID: 27178618, 2016.

18- MUSELLA M., MILONE M., MAIETTA P., BIANCO P., PISAPIA A. and GAUDIOSO D.: Laparoscopic sleeve gastrectomy: Efficacy of fibrin sealant in reducing postoperative bleeding. A randomized controlled trial. Updates Surg., 66 (3): 197-201 Epub2014 Jun 25. PMID: 24961471, 2014.

19- CARANDINA S., TABBARA M., BOSSI M., VALENTI A., POLLIAND C., GENSER L. and BARRAT C.: Staple Line Reinforcement During Laparoscopic Sleeve Gastrectomy: Absorbable Monofilament, Barbed Suture, Fibrin Glue, or Nothing? Results of a Prospective Randomized Study. J. Gastrointest Surg., 20 (2): 361-6 PMID: 26489744, 2016

20- CHANG P.C., TAI C.M., HSIN M.C., HUNG C.M., HUANG I.Y. and HUANG C.K.: Surgical standardization to prevent gastric stenosis after laparoscopic sleeve Gastrectomy: A case series. Surg. Obes. Relat. Dis., 13: 385390, 2017. 


\section{مقارنة لتقيييم دورتثبيت منديل البطن على مكان التدبيس

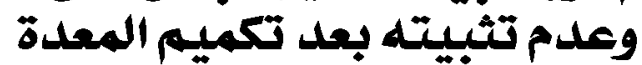

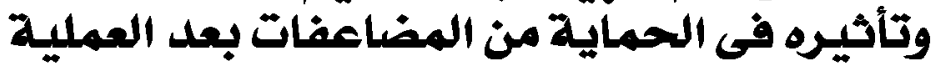

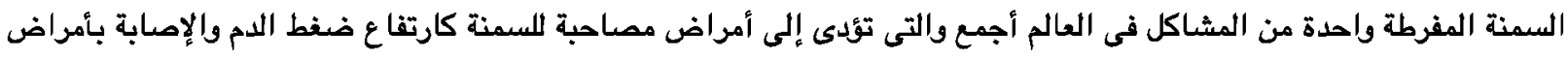

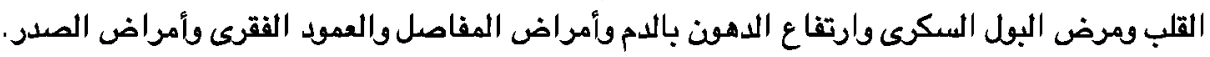

هناك الكثير من عمليات السمنة بالمنظار التى تساعد فى القضاء على السمنة المفرطة وأشهر هذه العمليات تكميم المعدة بالمنظار وتحويل مسار المعدة بالمنظار وهما من أكثر عمليات السمنة أماناً والتشاراً.

عملية تكميم المعدة هى أكثر عمليات السمنة شيوعاً حول العالم ولكن هناك بعض المضاعفات التى قد تحدث بنسبة قليلة بعد التكميم وهما النزيف أو التسريب.

هناك عدة محاولات لتقليل المضاعفات ما بعد العملية منها تشبيت منديل البطن على مكان التدبيس بعد تكميم المعدة وذلك لتقليل نسبة حدوث النزيف والتسريب.

هناك طرق أخرى لتقليل المضاعفات ما بعد العملية منها أخذ غرز على مكان التدبيس لتقويته أو طى خط الدبابيس باستخدام الخيوط

الجراحية.

كل هذه المحاولات لتقليل المضاعفات التى قد تحدث بعد عملية التكميم وقد تؤثر على حياة المريض. 